\title{
Dialectics of institutional change: the transformation of social insurance financing in Israel
}

\author{
Michal Koreh ${ }^{1, *}$ and Michael Shalev ${ }^{2}$ \\ ${ }^{1}$ School of Social Work, The Hebrew University of Jerusalem, Israel; \\ ${ }^{2}$ Department of Sociology and Anthropology and Department of Political Science, The Hebrew University of Jerusalem, \\ Israel \\ *Correspondence: korehm@mscc.huji.ac.il
}

\begin{abstract}
Social insurance financing is notoriously path-dependent, yet in Israel a series of unobtrusive changes ultimately led to the virtual elimination of employer contributions. This outcome is explained by combining insights into the politics and political economy of taxation with a theoretical approach to understanding institutional change which takes conflict seriously. Institutional arrangements typically emerge as settlements of inherently contradictory goals, and their foundational contradictions are not necessarily eliminated through processes of reproduction. Our case study illustrates how conflicting interests generate susceptibility to institutional change and shape its trajectories. While recent extensions to pathdependency theory suggest that institutions become vulnerable when returns decrease, we find that change may result from unbalanced returns (increasing for some while decreasing for others) or altered conditions which unleash repressed conflicts of interest. Further, in contrast to the expectation that institutional evolution follows a unidirectional path in which reversals are unlikely, we identify a dialectical trajectory which potentially includes the revival of seemingly foregone alternatives.
\end{abstract}

Keywords: institutional change, public finance, welfare state

JEL classification: 138 government policy, provision and effects of welfare programs, $\mathrm{H} 55$ social security and public pensions, H2O taxation, subsidies and revenue-general

This paper addresses two central questions in current theorizing on institutional change: Why do institutions become susceptible to change? And when change occurs, what are its characteristic trajectories? Until quite recently, most scholars viewed institutional change as a rare occurrence of breakdown, typically the result 
of an exogenously induced crisis. The imagery of institutions was that of a frozen sea, where change could only be effected by an ice-breaker that violently breaks the mould. At such critical junctures, the potential direction of change was indeterminate. However, as Thelen (2003) has described it, the 'static' understanding of institutions' normal functioning, which was the basis for the traditional approach, was subsequently replaced by a 'dynamic' interpretation of why institutions generally tend to stick to well-established paths. Stability was explained by path-dependent processes of reproduction based on mechanisms of increasing returns. This notion has recently been incorporated into explanations of change by the argument that institutions become susceptible to change when returns decrease. The imagery accompanying this theoretical view is one of a river slowly creating its bed in the downstream process. And like a river, the range of potential trajectories is limited by previous evolution, and there is no going back.

Institutional arrangements for financing the welfare state, which are the substantive focus of the paper, are often believed to be particularly prone to pathdependent processes of reproduction and consequently particularly difficult to reform (Sjoberg, 1999; Myles and Pierson, 2001; Kato, 2003). Such 'stickiness' is especially likely when income maintenance systems are based on contributions by insurees, which creates a sense of earned entitlement (Beland, 2005; Campbell and Morgan, 2005). The institutional resilience of contributory systems of social insurance turned into a major economic policy issue after the supply-side revolution in economics identified payroll taxes levied on employers as a potentially fatal barrier to employment creation-a perception emphatically endorsed by the OECD in its 1994 Jobs Study (OECD, 1994, 1995).

Both the pressure for reform and the obstacles imposed by entrenched veto players were especially pronounced in the most developed contributory systems (Myles and Pierson, 2001; Scharpf, 2001). The result was often a stalemate. At the turn of the millennium, European tax experts were hard put to find evidence of meaningful declines in the social insurance tax burden on employers. ${ }^{1}$ Nevertheless, both Palier's $(2002,2005)$ investigation of the French case and the research on Israel presented here reveal unexpected instances of successful but gradual reform. Between 1986 and 1995, the role of employers in financing social insurance in Israel was progressively and unobtrusively eliminated, and its cost was transferred in full to the government budget.

For reasons explained in what follows, the politics of the Israeli reform differed in important ways from expectations based on a European perspective. Yet its

\footnotetext{
${ }^{1}$ See the data assembled in a multi-country European study edited by Bernardi and Profeta (2004) and the explanations provided by Messere $(1998$, pp. 19, 291) indicating that cases of apparent retrenchment were actually illusory.
} 
peculiarities notwithstanding, the Israeli case offers a vivid illustration of a theoretical claim with universal relevance. Succinctly put, we argue that incorporating conflict into current theories of institutional change will enable scholars to better understand what renders institutions susceptible to change and to better identify likely trajectories of institutional evolution. While the modified theory of path dependence and other recent contributions to understanding institutional change have greatly enriched the field, in these two respects it still lacks a comprehensive explanation. The perspective advocated in this paper takes into account inherently contradictory goals and immanent conflicts of interests between actors, and it points to mechanisms other than increasing or decreasing returns that may play a critical role in institutional development and change. From a conflict-of-interests perspective, the process of institutional evolution is dialectical. Its imagery is that of a spiral which is driven by the fact that foundational conflicts may never be permanently resolved. At any time, tensions between actors and even among the interests of the same actor potentially undermine continuity by threatening the existing rules of the game. The changing balance among competing interests drives institutional evolution along a trajectory that may well include reversals inspired by discarded or forgotten alternatives.

The second theoretical contribution of this article is to identify specific sources of susceptibility to change that are characteristic of the political economy of welfare financing. The choice between contributory and non-contributory methods of paying for income maintenance programmes has potentially critical implications for state capacities to extract revenues and control expenditures. In addition, contributory systems may play an important role in implementing a counter-cyclical economic policy. Because each system has contradictory implications for existential state interests, the mode of finance on which institutions of social protection are based embodies a foundational conflict of interests. As our case study illustrates, if the relative importance of these interests changes in the course of time, institutions of welfare financing become susceptible to a dialectical process of change.

The section that follows introduces the conflict-of-interests approach to understanding institutional vulnerability and trajectories of institutional change by locating it in relation to other theoretical perspectives. We then offer a description of the transformation of social insurance financing in Israel and explanations for two puzzling features: why the reform aroused so little political opposition, and what motivated the Ministry of Finance (MoF) to engineer the reform. In explaining the Treasury's motives, we emphasize the conflict between controlling social expenditure, on the one hand, and extracting revenues on the other. This tension between the dual interests of fiscal bureaucrats is then shown to be a critical component of the specific dialectic that gradually 
transformed the system of welfare financing in Israel. The final section of this paper draws out the theoretical implications of our findings for the study of institutional change.

\section{Understanding institutional change}

In seeking to extend theories of institutional change in order to better understand welfare-state transformation, we join a distinguished body of literature that links these two domains of scholarly inquiry. As is well known, the seminal development in this respect was Paul Pierson's (1994) claim that the radical projects of welfare-state transformation pursued by Margaret Thatcher and Ronald Reagan were frustrated by the secondary political consequences of social policy. Pierson $(2000,2004)$ went on to further develop the concept of path dependence, which he borrowed from economics, where it was originally used to explain the tendency for early technology leaders to remain dominant (David, 1985; Arthur, 1989). Path dependence provides a powerful and appealing theoretical explanation of how political institutions generate feedback effects that often lock them into a fixed evolutionary trajectory. Perhaps the most significant challenge to this view in the area of welfare-state research is Hacker's (2004) claim that in the USA, what may seem like 'business as usual' actually hides real and significant changes. Along with related literature (see especially the collection edited by Streeck and Thelen, 2005), Hacker has called attention to gradual processes of change that are capable of subtly and often silently transforming institutions.

As a result of these developments, we now have a well-stocked analytical toolbox for identifying institutional change and uncovering the modes by which it occurs. Less progress has been made in dealing with the two questions on which this paper will focus. The first is the issue of what renders institutions susceptible to institutional change, and the second concerns the likely trajectories of institutional evolution and their linkage to past choices. In both of these respects, the path-dependency approach has limitations which have not been addressed in recent efforts to extend the approach or develop alternatives. Let us briefly describe these limitations.

Regarding the vulnerability of institutions to change, the most important suggestion in the current literature is that susceptibility appears when specific processes of positive feedback are eroded or exhausted (Lindner, 2003). This hypothesis adapts the notion of positive feedback, an explanation for continuity, to the task of explaining change. Path dependence implies that once an institutional path is chosen, it sets in motion a mechanism of increasing returns, as actors (including those who previously opposed this path) adjust their strategies to accommodate the new rules of the game. As a result, the price of forgone alternatives increases and the likelihood of their adoption declines over time. 
By turning the idea of increasing returns on its head, Thelen $(1999,2003)$ was able to show that it can account for situations where either exogenous or endogenous developments undermine the benefits of institutional arrangements for actors who, as a result, may seek to change these arrangements. However, we believe that this approach suffers from a serious limitation which becomes apparent when attention is paid to conflicts of interest that are built into institutions.

Few sociologists or political scientists would disagree with the proposition that institutions are not only functional organs of coordination aimed achieving collective goals, but also structures of power and conflict (e.g. Knight, 1992; Korpi, 2001). However, as Moe $(1990,2005)$ has noted, for the most part the theoretical implications of this insight have yet to be fully internalized. Institutions consist of webs of rules that embody a particular settlement of conflicting interests. Path-dependency theorists correctly point out that by rearranging actors' options and incentives, institutions may open the way to the discovery of unanticipated gains from cooperation (Thelen's study of occupational training in Germany offers a celebrated example). At the same time, compromises by definition have zero sum as well as win-win elements.

Given these foundational conflicts, as they are termed here, the returns from functioning institutions are not necessarily joint costs and benefits, but may instead be asymmetrically distributed. Some actors may experience increasing returns while others suffer losses. At a minimum, some may receive more gains or bear more burdens than others. This challenges the assumption that at any given moment returns are straightforwardly either positive or negative. It suggests that vulnerability to change may be explained by returns which are unbalancednot only between different actors but also, we will argue, between different interests of the same actor. ${ }^{2}$ On the other hand, if the foundational conditions which originally motivated actors' compliance with institutional arrangements continue to prevail, this in itself should be sufficient for stability, without any need for increasing returns. Vulnerability to change occurs in the opposite case, in which changed conditions unleash repressed conflicts of interest that then threaten to undermine the value of institutional arrangements.

Turning now to trajectories of institutional change, Pierson argues that even though the 'self-reinforcing processes' identified by path dependency tend to drive institutional evolution in a more or less linear direction, the theory is not deterministic. Other theorists argue for a stricter interpretation, positing that only when 'critical junctures' are reached or equilibrium is 'punctuated' by a shock to the system does a range of developmental paths become feasible

\footnotetext{
${ }^{2}$ Other scholars have made a partly similar point, noting that increasing returns are not necessarily spread evenly among all spheres of an institution. This may explain cases of partial institutional change, in which some elements shift while others stay in place (Thelen, 2003; Pierson, 2004).
} 
(e.g. Mahoney, 2000). Nevertheless, there is universal agreement that the defining claim of path-dependency theories is, as Hacker puts it, that 'developmental trajectories ... are inherently difficult to reverse' (Hacker, 2002, emphasis added; for similar formulations, see David, 1985; North, 1990). The improbability of reversals is explained by the adaptive responses of the actors (including those who previously opposed the chosen path) reacting to incentives to accommodate themselves to the new rules of the game. With time, the price of previously plausible alternatives increases and the likelihood of their adoption declines. Absent a cataclysm, therefore, institutional development should follow a unidirectional trajectory.

Several recent contributions have challenged this prediction by asserting that institutional change often occurs through reconfiguration rather than either incremental adaptation or rebuilding from the ground up. In particular, institutional entrepreneurs may operate as eclectic bricoleurs, engineering change by returning to old or marginalized options and recombining them with current practices (Campbell, 2004; Crouch, 2005). This approach challenges path dependency theoretically by questioning its assumption of institutional homogeneity. In relation to policy change, the argument is that since states are heterogeneous systems that incorporate diverse institutional legacies, actors operate simultaneously in different institutional settings governed by different logics and move back and forth between them. In the context of this diversity, at any one time some components play a dominant role and others a subordinate one; but the prevailing mix should be understood as contingent rather than stable. Our challenge to the prediction of unidirectional evolution rests on a different theoretical insight. Insofar as institutions embody conflicts that may never ultimately be settled, institutional stability is contingent on the continuously renewed challenge of managing foundational conflicts of interest. Under certain circumstances, which could be either endogenous or exogenous to institutions, forces that were previously overpowered and interests that were temporarily repressed may rally and succeed in moving an institution towards a new and quite different equilibrium.

The relationship of institutions to conflict, and the resulting implications for trajectories of institutional development, has long been a contested issue in political sociology. Path-dependency theory-indeed, neo-institutionalism in general-does not deny that institutions may be born in conflict, but regards stability as a likely outcome of the fact that institutions are capable of redefining interests, thereby motivating actors to operate under rules that preclude or limit expressions of conflict. This resembles the argument made many years ago by theorists like Coser (1956) and Dahrendorf (1959) regarding the institutionalization of class and other social conflicts. These theorists also treated conflict institutionalization as synonymous with institutional stability. However, critics like Korpi 
(see especially Korpi, 1974, 2001) have suggested that the readiness of parties with conflicting interests to accept collaboration in lieu of confrontation should be understood as contingent on the persistence of the underlying balance of power which prevailed at the moment of institutionalization.

It can also be argued, as we do, that because institutionalized settlements compromise (some of) the interests of the parties concerned, those interests may regain salience long after the original settlement is reached. A familiar example from the field of class conflict is the manner in which the Swedish 'historic compromise' of the 1930s was reopened decades later, first by trade unions wielding their political power in order to alter the original settlement by imposing legislated mechanisms of 'economic democracy', and then by organized employers using their economic might to restructure the industrial relations system and mount a successful political counter-attack on the unions' reform initiatives (Pontusson and Swenson, 1996; Blyth, 2002). This example reminds us that, as Korpi (2006) has put it, the fact that actors consent to institutions which fail to satisfy their first-order preferences does not mean that these preferences are necessarily abandoned (see also Hacker and Pierson, 2002). Consequently, without discarding the insight that institutions may be sustained by returns which simultaneously create and satisfy second-order preferences, it is critical to recognize that actors may continue to have conflicting first-order preferencesbetween themselves and even 'within themselves'. This can explain why institutional alternatives which were discarded in the first round sometimes become relevant at a later stage, and vice versa. If conflicting first-order preferences are revived, institutions can be expected to follow a dialectical trajectory of development in the shape of a spiral. This trajectory should be seen as theoretically complementary to both the unidirectional prediction implied by path dependency and the bricolage dynamic. All three are plausible paths of institutional development.

The concluding section of the paper discusses additional theoretical implications of this alternative approach to deciphering institutional equilibrium and change. Prior to that, we present our case study of the unannounced transformation of social insurance financing in Israel from a fully contributory to a partially non-contributory system. This is a case which exemplifies the role of foundational conflicts of interest in both generating susceptibility to institutional change and sparking a dialectical trajectory of change. From its beginnings, the financing of social security in Israel was beset by inherent contradictions. Tensions between the interests of different actors, and contradictions between the goals of each one of them, were repeatedly resolved only to reappear at a later stage. The consequence was a slow-moving but radical change in fiscal politics. 


\section{The reform of social insurance financing in Israel}

Responsibility for managing and implementing social insurance in Israel is vested in the National Insurance Institute (NII). The NII collects taxes and distributes benefits for social insurance programmes covering the typical range of risks, and it also disburses social assistance and a variety of other non-contributory benefits. ${ }^{3}$ In order to guarantee its financial autonomy, the Institute, by design, has its own apparatus for revenue collection. Until the mid-1980s reform, its revenues were based primarily upon earmarked contributions paid by insured workers and their employers. However, beginning in 1986, employers' contribution rates to the NII were successively reduced and by the late 1990s had been virtually eliminated. The resulting reduction in the state's revenue base has been far from trivial. For example, in 2005, lost revenues were estimated as 9.3 billion Israeli shekels, equivalent to nearly one-quarter of the government's entire expenditure on income maintenance. ${ }^{4}$ Reductions in employers' contribution rates were accompanied by special allocations from the Treasury fully compensating the NII for lost revenues. Partly as a result of these so-called 'indemnity' payments, after years of playing a secondary role the government became the NII's most important source of funding (Doron, 1999; Koreh, 2004).

The declining social insurance burden on employers, compared with the stability of wage-earners' contributions, is graphically portrayed in Figure 1. Whereas in 1985, on the eve of the first reduction, the payroll tax was nearly twice as high as the tax on wages, in 1987 they came close to parity. As a result of further reductions, from 1991 onwards employers were required to pay less than half of the employee rate. In addition, between 1986 and 1990, the Treasury periodically offered employers ad hoc relief by relieving them of the obligation to make upcoming quarterly payments to the NII. Whether the subsidy was implemented through rate reductions or by foregoing due debts, the MoF fully indemnified the NII for forgone revenues. The result was that while in 1985 insured workers, their employers and the self-employed were together responsible for $80 \%$ of the financing of the contributory benefits administered by the NII, by the mid-1990s the tables were turned. As a consequence of taking over the bulk of employers' obligations, and due also to an increase in the state's statutory obligations at the end of the period, the

\footnotetext{
${ }^{3}$ See http://www.btl.gov.il for further information on the NII. Using OECD definitions of public expenditure, in 2006 the NII distributed 85\% of all cash benefits, excluding civil servant pensions (NII Annual Survey for 2006, Section E15, Table 2). The residual 15\% is made up of categorical benefits disbursed by other public bodies (Gal, 1998).
}

${ }^{4}$ Source: Lost revenues_Zadik (2006); total expenditure-Kop (2006, Table 1). 


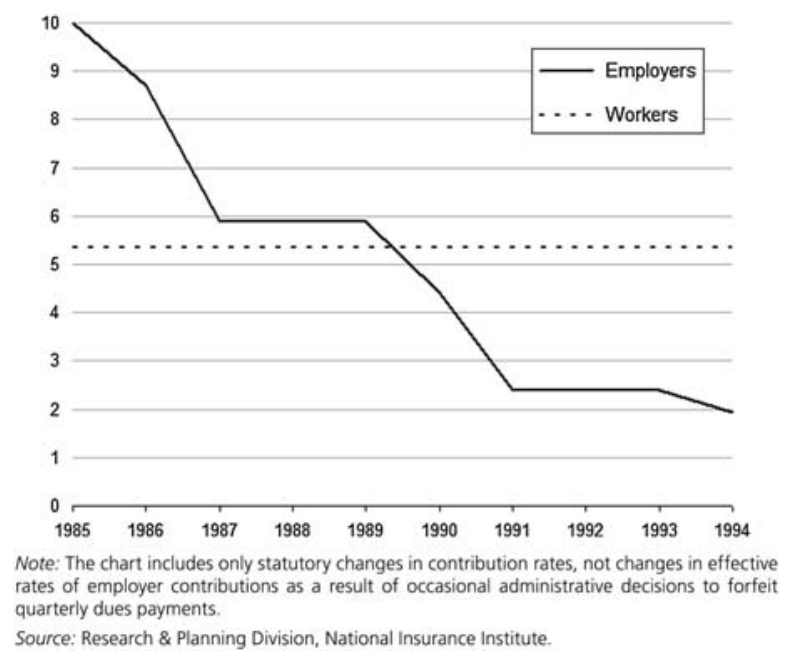

Figure 1 Social Insurance Contribution Rates, Israel 1985-1994.

government's share rose from $20 \%$ to almost $60 \% .^{5}$ After 1995 , technical changes in the insurance system complicate the calculations, but in essence there has been no diminution of the state's role in absorbing employer charges since the mid-1990s. ${ }^{6}$

The series of cuts in employer contributions carried out in the second half of the 1980s were justified by the MoF as a means of sustaining price stability and fostering exports. At the beginning of the decade, inflation in Israel had ratcheted to crisis proportions, and in July 1985, the government adopted an emergency stabilization plan that succeeded in rapidly reducing price and wage increases (Bruno, 1993). One of the essential features of the plan was that the government ceased to drive one of inflation's most toxic transmission belts: repeated devaluations aimed at defending the profitability of exports in the face of increases in

\footnotetext{
${ }^{5}$ As noted, this calculation refers only to contributory (insurance-based) benefits. Since the mid-1990s, about one-fifth of the benefits disbursed by the NII are non-contributory and are financed entirely through the government budget. Between 1984 and 1995, the government's share of all NII revenues, including this component, rose from one-third to two-thirds. All figures cited in this note and the body of the text are authors' calculations based on data supplied by the Research and Planning Division of the NII in July 2009.

${ }^{6}$ In 1995, a dual rate structure was introduced, which imposed a higher tax rate on both workers and employers for portions of the wage above a certain threshold. More importantly, when Israel's National Health Insurance Law came into effect in 1995, the NII was enlisted as its collection agency. Two years after the law came into effect employer contributions were cancelled, but their contributions to the social insurance system were equivalently increased. As we explain later in this paper when touching on the financing of health insurance, this relabelling was a tactical move by the MoF designed to provide it with greater control over the state's obligations for financing health care.
} 
wage and other domestic costs that were themselves driven by previous devaluations. One year into the stabilization process, in the face of declining profitability and erosion of wages in powerful segments of the economy, policymakers faced the prospect of new rounds of price and wage increases and were under pressure from exporters to implement further devaluations. In July 1986, the Treasury pre-emptively responded by unilaterally reducing employers' social contributions at its own expense. This was presented as a temporary measure and was enacted by administrative means. A further cut was implemented at the beginning of 1987 as part of a tripartite 'package deal' between the state and the peak associations of labour and industry, again with the intention of compensating the employers and assuring their commitment to price stability (Grinberg, 1991, Chapter 6). Reductions in employer contributions continued in the course of the 1990s, but with inflation under control and unemployment occupying the limelight, lowered contribution rates were now justified by the MoF as a means of reducing labour costs in order to encourage the creation of new jobs for the massive wave of immigrants arriving in Israel from the former Soviet Union.

Reflecting upon the financing reform, one is struck first of all by its remarkable scale. As noted at the outset, tax systems in general and social insurance taxes specifically are considered to be particularly path-dependent. Even in countries that have managed to introduce reductions in employer contribution rates, the scope of reform appears to have been far more modest than in Israel (Palier, 2005). Two evident underpinnings of the reform's success are particularly surprising. First, in an era of retrenchment, it is odd to find a Ministry of Finance that first initiates and then expands an institutional change that substantially increased the budget deficit. Moreover, in other countries, campaigns to lower payroll taxes have naturally been led by employer associations. The proactive role of the MoF seems especially incongruous when one considers that in the same period it was actively committed to a neo-liberal restructuring of the political economy. In this context, the Treasury was not only engaged in struggles to reduce the deficit, but had also embarked on structural reforms aimed at ending other types of state subsidies to firms. The MoF's role in reforming social security financing is equally surprising when viewed from a historical perspective. The ministry supported the adoption of a contributory system when national insurance was first established. Later, it was a key proponent of subsequent expansions of social security taxes, including payroll taxes.

The second puzzling reason for the success of the financing reform is that decision-making was far less conflictual than would have been expected, given the high stakes involved. Far from being turbulent and politicized, the debate over eliminating employer contributions was muted and the decision-making 
process unfolded far from the public eye. Particularly surprising, at least for observers unfamiliar with the Israeli context, was the absence of any real opposition on the side of either the labour unions or the Labour Party. After all, the inescapable implication of the MoF's drive to shift the cost of social insurance payroll taxes to the government budget was that taxpayers at large were being obliged to finance a subsidy to employers. In addition, as supporters of the social security system pointed out early in the reform process, relieving employers of their financial obligation to the system also had worrisome implications for the future of income maintenance (Koreh, 2004). Though the NII was fully compensated for its lost revenues, the reform eroded its prior financial autonomy and, in making it dependent upon general revenues, rendered its programmes potentially vulnerable to across-the-board cuts in public spending. The new funding arrangement also contributed directly to retrenchment pressures by diminishing the state's available revenues. ${ }^{7}$ Finally, by seriously undermining the insurance principle - the notion that social entitlements are individually 'earned' by the joint contributions of workers and their employers - the reform weakened potential resistance to cutbacks by beneficiaries.

The lack of successful opposition to the phasing out of employers' social charges can only be understood against the background of distinctive features of the politics and political economy of Israel. The Labour Party dominated Israeli governments until 1977; until the 1990s, its close ally, the Histadrut, was the most encompassing and powerful peak organization of labour in the developed non-Communist world; and the two arms of the labour movement effectively constructed Israel's highly dirigiste political economy. Taken together, these characteristics appear to be a larger-than-life version of European social democracy. In practice, the character of Israel's labour organizations and parties was shaped in the era prior to Israel's establishment in 1948, when they were primarily committed to developing the economic, demographic and political infrastructure for a future Jewish state (Shalev, 1992; Sternhell, 1998; Shafir and Peled, 2002). In the political arena, the key divisions between left and right always revolved primarily around disputes over borders and national identity-not the articulation of competing class interests. The typical class basis of support for left and right is actually reversed in contemporary Israel (Shalev, 2007), but in any case both Labour and its main rival the Likud have tended to endorse broadly similar economic and social policies. In the past, this consensus mandated an East Asian-style developmental state, harnessed to Zionist goals (Levi-Faur, 1998). However, and without having abandoned these

\footnotetext{
${ }^{7}$ Indeed, apparently in order to ensure that this point would not be lost on politicians and the public, the MoF chose not to treat the subsidy like other tax exemptions, i.e. as an implicitly missing sum on the revenue side of state finances, and included it in the budget as an explicit tax expenditure.
} 
goals, since the 1980s both left and right have largely joined the consensus among academic and bureaucratic economists in favour of capitalist-led growth and neoliberal restructuring of the political economy (Kleiman, 1998; Ben-Bassat, 2002; Shafir and Peled, 2005).

Until the 1990s, when its many non-union functions were either nationalized or privatized, the Histadrut was unique among peak labour organizations (Shalev, 1992; Grinberg and Shafir, 2000; Ben-Bassat, 2002). The labour organization's health clinics and occupational pension funds substituted to a large extent for either market or state provision of these critical areas of social protection (Rosenhek, 1998). The Histadrut was also the owner of one of Israel's three largest banks, the lynchpin of a vast economic empire employing one-quarter of the labour force. Both the economic and social functions performed by the labour organization were extensively subsidized by the state, which also nurtured a privately owned sector of big business. These private firms developed a collaborative relationship with top Histadrut executives and officials, and in the era of economic crisis which preceded the events recounted here, they formed a powerful distributional coalition that often enjoyed decisive influence over government economic policy (Grinberg, 1991).

Against this background, it is not difficult to explain many of the seemingly puzzling features of the reform of social insurance financing in Israel, beginning with the cuts in employer contributions that were implemented in the wake of the 1985 stabilization programme. Previously, large firms - those whose representatives signed the 'package deal'-had been willing to live with rising payroll taxes and other burdens because they were compensated by an array of direct and indirect subsidies. Although in late 1986 their eyes were on other concessions, especially devaluations, organized employers were not unhappy to accept the subsidy embodied in reduced social charges. The Histadrut added an additional sweetener by agreeing to forgo a scheduled cost of living allowance, which at the time was an integral component of earnings. Its motivation was both to satisfy its own interests as an employer and to induce the government to provide badly needed subsidies for its ailing social services and economic enterprises (Grinberg, 1991, pp. 149-150).

It is also important to recognize that unlike the 'Bismarckian' welfare states of Continental Europe (Ferrera, 1996), the social insurance system in Israel was not managed by workers' representatives or jointly by the social partners, but by professional social administrators. Consequently the labour organization had no direct institutional interest in defending the social insurance system. Indeed, in the early years, the Histadrut treated the social insurance system as a potential competitor in relation to the occupationally based programmes (foremost pensions), which the labour organization either controlled or wished to take credit for (Doron, 1988). At the same time, the organization's leaders could not afford to face the wrath of members-especially those with significant workplace 
power-by blatantly flouting their interests. But the fact that the financing reform shifted employer obligations to the state rather than to the workers prevented it from being seen in this light.

Not only did the associational representatives of labour and capital fail to play their anticipated roles in opposing or advocating government subsidy of employers through cuts in social charges; given, in addition, the absence in Israel of parties dedicated to the political articulation of class interests, the public defence of those who stood to lose from the reform-including the NII-was also left to a small band of pro-welfare-state legislators acting as individuals (who would be joined in later years by the representatives of advocacy groups). Under these circumstances, the most important political dynamics were initiated by the relevant bureaucratic elites, whose tactical interests lay in either politicizing the reform (the NII) or preventing its politicization (the MoF).

Documentary evidence and interviews indicate that at the time of the first moves in the reform process, the NII almost certainly made discreet efforts to mobilize sympathetic parliamentarians and journalists. But in the first few years following the stabilization plan, the state was publicly perceived as engaged in a vital struggle against the return of hyper-inflation. This made it politically risky for the NII to be seen as trumpeting its own interests in the face of what the Treasury took pains to present as a purely technical matter that fell within the province of its professional expertise. The MoF acted to pre-empt controversy through its low-key packaging of the benefit cuts when they first came under parliamentary scrutiny in the spring of 1987. It also adopted a tactic applied to other potentially controversial proposals for structural reforms in the post-1985 era: tying approval of the reform to the process of enactment of the annual Budget Bill (Koreh, 2003). This practice limits the build-up of opposition by placing strict time constraints on debates, creating an unmanageable legislative load and imposing party discipline on coalition members. Moreover, policy proposals are automatically routed to the Finance Committee rather than to the substantively relevant body-in this case the Labor and Welfare Committee, which would probably have vetoed the reduction in employer charges. ${ }^{8}$

Our first puzzle - why the reform engendered so little political conflict-has now been resolved. Peculiarities of the Israeli context resulted in deviations from standard expectations concerning both the character and the interests of

\footnotetext{
${ }^{8}$ The skill of Treasury officials in the field of preventive depoliticization has also been noted by other students of economic and social policymaking in Israel (Lein, 2000; Ratson, forthcoming), as has the extraordinary degree of institutional autonomy enjoyed by the MoF when the Israeli case is assessed from a comparative perspective (Ben-Bassat and Dahan, 2006). Nevertheless, these attributes are more developed in the present decade than they were in the 1980s. This in turn is the result of a sustained organizational and ideological campaign for autonomy, the reasons for which are noted in the next section of the paper.
} 
key actors in the field of social and economic politics. The reform effort was further supported by the success of tactical moves by the MoF that were designed to pre-emptively depoliticize the decision-making process.

Our second puzzle - why the MoF acted to gradually revolutionize the system of social insurance financing - has yet to be addressed. Maintaining price stability and later lowering labour costs were the immediate reasons. However, these challenges were not new, and reducing employer contribution rates was certainly not the only way to deal with them. The Treasury's decision to adopt this measure connects directly to our theoretical proposition that unresolved conflicts of interest are capable of sparking institutional change along a trajectory that even today's enhanced versions of the path-dependence model fail to anticipate. The task before us is to locate the source of the financing system's vulnerability to change, and to trace the dialectical process by which the MoF redefined its interests with respect to the system. In order to carry out this task, we will first explain why the fiscal interests of states are inherently ambivalent. Then we will show that in the context of Israel's political economy circa the mid-1980s, this ambivalence revived the salience of interests that had hitherto been sidelined by existing institutional arrangements. That is why those arrangements became vulnerable to change.

\section{Dilemmas of welfare-state finance}

Ministries of Finance are the bearers of a core existential requirement for the establishment and viability of states: their ability to extract revenues. The burgeoning field of fiscal sociology is well aware of the significance of this truism, yet it has paid surprisingly little attention to disaggregating the state and specifying the interests of the agencies directly responsible for tax policy and tax collection (see, for example, Campbell's 1993 seminal synthesis of the field). Even the specialized literature on the politics of social insurance financing cited in previous sections of the paper attends primarily to conflicts of interests between the state and its citizens and among different societal groups.

Although related to the wider field of public finance, the financing of social insurance has distinct features with weighty implications for understanding the role of the Treasury. In a social insurance system, benefits are paid for by some combination of general revenues (taxes on income, consumption, etc.) and mandatory contributions from employers and employees. These contributions constitute a fund of their own, separate from the state budget and earmarked for specific income maintenance schemes (Campbell and Morgan, 2005). The attention of social policy experts has naturally been drawn to the effects of different modes of social security financing on citizens' eligibility for social rights (e.g. Titmuss, 1958). More important for our purposes is the insight that the 
seemingly technical difference between contributory and non-contributory finance taps into tensions between what the literature terms fiscal and social bureaucrats (Yang, 2004; Asiskovitch, 2009). This results from the profound implications of the two modes of finance for the state's ability to control social expenditure, on the one hand, and to extract revenues on the other.

In non-contributory systems, where benefits are financed through general revenues, the MoF has the capacity to exert centralized control. Since all social revenues and expenditures pass through the MoF apparatus, it is relatively simple to move resources from one domain to another and to implement spending cuts. Consequently, this is also an important source of power for fiscal bureaucrats over social bureaucrats. Furthermore, in the absence of the perceived linkage between individual contributions and benefits, which is a pillar of contributory systems, there is less political pressure to spend and more reliance on residual social assistance for those with acute and demonstrated need. And because residual benefits are discretionary rather than an entitlement, it is politically easier to tighten eligibility criteria once the allocated budget runs out. Social assistance programmes by nature are offered to only a limited number of beneficiaries, further enhancing the potential for budgetary control (Brodsky et al., 2003).

In contrast, in a contributory system, funds are collected and earmarked for specific purposes, and they are managed by an independent government bureaucracy and/or by representatives of the 'social partners'. In addition, when the workforce expands or earnings increase, revenues from contributions rise correspondingly. Greater availability of earmarked resources tends to create pressures to raise spending. At the same time, two quite different political dynamics may render it politically difficult to retrench the entitlements offered by contributory systems: either because they facilitate broad political coalitions between working and middle-class beneficiaries (Korpi, 1978), or because they tap into the power of 'insider' groups (Rueda, 2005). Residual means-tested benefits, on the other hand, make it easier to build political coalitions in support of retrenchment (Korpi and Palme, 1998; Wilensky, 2002).

Despite these evident disadvantages of contributory financing from the viewpoint of expenditure control, it offers an overwhelming advantage on the revenue side of the fiscal equation. This is especially the case when contributions surpass expenditures and the resulting surpluses are invested in state bonds and added to the capital budget. This advantage was fully recognized by the founders of both the German and American systems of social security (Leff, 1983; Manow, 1997; DeWitt, 2007). ${ }^{9}$ Later, during the first two post-war decades, many governments moved towards contributory systems in a drive to increase their revenues

\footnotetext{
${ }^{9}$ The founders of social security in the USA initially believed that the contributory structure of the system would restrain popular demands for expanding the system. Because of distinctive political
} 
(Heidenheimer et al., 1975; Sjoberg, 1999; Wilensky, 2002). One motive for this change was to provide a macroeconomic instrument for Keynesian fiscal management by using social taxes to cool down an overheated economy (providing of course that the cost of benefits fell short of revenues from contributions). In addition, governments found that there was less political resistance to raising earmarked contributions to social security than to increasing taxes on income or property. Wilensky explained this as resulting from the connection between tax 'visibility' and susceptibility to tax revolts. The relative invisibility of social contributions is connected in part to the role of employers in social insurance. Even though it can be argued that the cost of employer contributions is actually passed on in the form of either higher prices or lower wages, workers perceive charges on employers as lowering their own tax burden. In addition, social contributions are more favourably regarded than other taxes because they can be expected to yield benefits in the future (Doron, 1999; Wilensky, 2002). Ministries of Finance therefore face an unavoidable dilemma in the financing of income maintenance: while a contributory system facilitates revenue collection, it hampers the control of state expenditures.

A third universal concern of MoF officials is steering macroeconomic policy. As noted earlier, when economic policy follows the Keynesian paradigm, social insurance contributions can be raised to help restrain the inflationary consequences of economic growth. In contrast, under the neoliberal paradigm, fiscal policy is premised on controlling spending to cope with 'permanent austerity' (Pierson, 1998), while macroeconomic management is oriented towards the supply side of the economy. From this perspective, employers' social insurance contributions and other payroll taxes are seen as a disincentive to job creation.

Thus, at any given time, the interest of fiscal bureaucrats in different institutions of social insurance financing depends on the relative importance of two possible first-order preferences: maximizing revenue extraction versus maximizing expenditure control. Our exploration of the Israeli case in the 1970s and beyond will indeed show that this choice is intimately linked to the overall role of the state in managing the economy. But first we need to provide some essential background regarding the formative decisions on social insurance financing in Israel and how the system accommodated the interests of the fiscal and social bureaucracies in the earlier phases of its development.

\section{How the political economy of the Israeli system evolved}

The founding of the NII in 1953 followed five years of intensive deliberations. In addition to the issues of which social programmes should be included and their

and institutional conditions of the American setting, to some extent they turned out to be right (Campbell and Morgan, 2005). 
criteria of eligibility, the founders also debated appropriate financing methods (Doron, 1975, 2004b). Three main alternatives were discussed: (a) a statist system operated and financed by the government using existing forms of taxation; (b) multiple insurer organizations financed exclusively by contributions; or (c) a single social insurance institution financed by contributions, with or without state participation. Separation from the state was perceived as necessary in order to achieve autonomy and prevent misuse of resources, while at the same time state participation was seen as important for promoting equity, uniformity and stability. Consequently, the first and second options were discarded, and the third method of social insurance, based on a tripartite structure of finance (employers, employees and the state) became the preferred choice.

The social security planners knew, however, that they would be unable to implement any programme without the approval of the MoF. This was a period of sharp austerity. A newly established state, immediately embroiled in war, set about absorbing vast numbers of new immigrants in the context of a weakly industrialized economy. Under these circumstances, the government and the MoF were reluctant to accept any policy that implied a binding expenditure commitment. Their eventual support for the establishment of the NII was gained only after the MoF realized that a contributory system supported by employers and employees would not only cover the cost of NII disbursements but would also provide a significant source of additional revenue. This was due to the combined effects of the youthful demographic structure of the new state and the conditioning of individual entitlement on a history of paying into the system. And indeed, for a long time, contributions to the old-age benefit programme-by far the largest—surpassed expenditures (Doron, 1975; Barkai, 1998).

In this specific historical context, the new institutional configuration made it possible for both fiscal and social bureaucrats to achieve their partially contradictory goals. The NII enjoyed an autonomous position, as it received earmarked contributions and was not dependent upon budgetary allocations. Indeed, since contributions exceeded expenditures, significant surpluses were created, which were invested in government bonds and added to the capital budget. In its first decade, on average the NII transferred more than $40 \%$ of its revenues to the state (Morag, 1967; Doron, 1975). As in other countries (Wilensky, 2002), this approach enabled the MoF to extract substantial revenues from the public at a politically negligible price. In 1955, for example, NII contributions were equivalent to more than one-third of direct taxes and constituted $10 \%$ of all tax revenues (Barkai, 1998). The surplus of contributions over benefits was perceived a mechanism of 'fiscal absorption' and as such a legitimate instrument of macroeconomic policy. Indeed, in seeking to enlist MoF support for the proposed National Insurance Institute Bill, Minister of Labor Golda Meir proudly 
drew attention to 'its contribution to the battle against inflation. ${ }^{10}$ In practice, social insurance surpluses were invested in government bonds (Morag, 1967; Barkai, 1998), providing the wherewithal to finance public investment and subsidize large private and Histadrut-owned enterprises.

During its first two decades of operation, the scope and volume of the NII's disbursements were relatively small. While new programmes were introduced and coverage extended, overall expansion was minor. In this period, increases in contribution rates were also relatively moderate. But in 1970, partly in response to unprecedented political turbulence among the poor, the government accepted NII reform proposals that ushered in an era of massive expansion of the social insurance system (Hoffnung, 2006). An amendment to the NII Law sharply raised both contribution rates and the ceiling of taxable earnings, resulting in a doubling of NII revenues. Social charges on both employers and employees continued to rise, peaking in 1978 at a combined level of $17 \%$ of the base wage, three times the initial rate set in 1953.

Analyses of Israel's entry into what later came to be seen as the golden age of social insurance have generally attributed the expansion of the 1970s to the demonstrated inadequacies of the existing social safety net in a context of political pressure for change (Avizohar, 1978; Doron and Kramer, 1991; Gal, 2004). However, the political economy of the reforms suggests an additional interpretation. The leap in revenue extraction that began in 1970 was seen at the time by economists and economic policymakers as having beneficial macroeconomic effects, because it coincided with a crisis in the balance of payments that was fuelled in part by rising consumption of imported goods. Prior crises of this kind had been dealt with by rationing in the early 1950s, and by unleashing the full force of recession in the mid-1960s. However, by 1970, both approaches were perceived as politically out of the question (Dinstein, 1969; Frumkin, 1969; Horowitz, 1970). The alternative was to dissipate the public's purchasing power through increased taxation. At that time, Israel's overall tax burden was considered to be low, and the rates applied to social contributions were singled out as especially laggard compared with OECD countries (Berglas, 1969). On the other hand, income tax rates were regarded as high and the state was reluctant to raise them (Achiram, 1969; Berglas, 1969). Increasing NII contributions was therefore seen as a politically feasible option likely to avoid tax backlash. To further pre-empt political resistance, the decision to double NII contributions was included in Israel's first formal 'package deal' between the state and the peak organizations of workers and employers, in 1970 (Galin and Tabb, 1971).

Although the MoF sought to leverage insurance contributions for fiscal and macroeconomic purposes, it found allies at the head of the NII and the Ministry

${ }^{10}$ Knesset record, February 5, 1952, p. 1213. 
of Labor who identified the changed climate for funding as an opportunity to expand the social insurance system. The director of the NII voiced this motivation quite explicitly before the parliamentary Labor and Welfare Committee in 1970, when NII supporters expressed concern that the Treasury would divert social insurance taxes away from their intended purpose.

In regard to the financial expansion of the NII: We at the Institute are not naïve, as it might seem, and we are aware that not all of the funds we collect will immediately benefit the insured... However, I am not aware of any social insurance fund which was able to raise benefits or expand coverage without having the necessary funds. Raising contributions now empowers the NII, as the funds are earmarked for social insurance. $^{11}$

This working assumption was basically confirmed. The social insurance system expanded more or less parallel to the growth of funds available, and at a rate far exceeding economic growth. ${ }^{12}$ During the 1970s, new NII programmes were introduced, benefits were increased and coverage was expanded. The Treasury's interest in fiscal absorption was pointedly expressed in the case of two new programmes, unemployment insurance and general disability insurance, which were both designed so that the collection of contributions would begin before entitlements came into effect. As Martin (1991) has argued in a different context, tax policy is typified by shifting and sometimes improbable coalitions between interested parties. This is certainly true of the alliance between politicians, social bureaucrats and fiscal bureaucrats which underpinned the remarkable expansion of contributory social insurance in Israel. Needless to say, however, such alliances are not written in stone. We already know in hindsight that the Treasury's appetite for payroll taxes subsequently turned into an aversion so deep that it launched a campaign to eliminate employers' social security charges at its own expense. Having offered an account of the history and political economy of social insurance financing in Israel prior to this reversal, with the help of our conflict-based theoretical approach to institutional evolution we are now ready to probe the motives of the MoF in initiating the reform.

\section{The transition to non-contributory financing}

In many respects, Israel's contributory system of social insurance generated a virtuous circle of increasing returns which supported the system's reproduction.

\footnotetext{
${ }^{11}$ Knesset, Labor Committee, Protocol no. 16, March 18, 1970.

${ }^{12}$ According to Barkai (1998, p. 5), between the years 1965-1969 and 1975-1979, the share of NII benefits in GNP rose from 2.2 to $5.7 \%$.
} 
Growth in contributions expanded the availability of earmarked revenues, which in turn created pressures to expand entitlements, leading to increased contributions and so forth. Reinforcement mechanisms also followed from the introduction of new entitlements that included ever broader circles of beneficiaries. As Pierson (1994) famously argued, such a process generates vested interests in the maintenance of the system, thereby increasing the political and fiscal costs of retrenchment.

Accordingly, the radical (if at first only partial) change in the system which occurred in the mid-1980s comes as a theoretical surprise. The direction of the change is also unexpected from the perspective of path-dependency theory, because the system in effect returned to a path not taken. As anticipated by scholars who expect institutional development to rest on bricolage, a previously discarded option-government financing of the social security system-resurfaced and was gradually put in place. Our interpretation of this transformation is that it reflected a change in the state's fundamental political-economic strategy. As a result of this change, the Treasury came to award precedence to budgetary restraint (control of expenditure) over its prior preference for maximizing social insurance taxes as an instrument of fiscal absorption (control of revenues). Neither a focus on mechanisms of reproduction, nor the more traditional theoretical emphasis on cataclysmic change, can explain the trajectory followed by institutional development in this instance. Instead, we propose to focus attention on inbuilt contradictions and inherently conflicting goals. Questions must then be raised concerning the mechanisms by which these tensions were addressed, beginning with the initial settlement that led to the establishment of the national insurance system. Did this settlement succeed in ending the tensions, or only temporarily settling them? Was equilibrium reached between conflicting interests, and if so, on what essential conditions did this equilibrium rest? After answering these questions, we shall move on to the issue of how initial areas of conflict evolved to the point where they became responsible for major institutional changes.

It has already been made clear that there is an inherent tension between the NII and the MoF which derives from their opposing institutional logics. The former operates to expand social rights, benefits and services, while the latter, being the guardian of the public purse, typically seeks to limit expenditure. But the analysis also identified a contradiction between multiple interests of the MoF, as it is responsible not only for the budget but also for steering economic growth and guaranteeing the availability of resources which are essential for the operational viability of the state. These three functions, though strongly linked, may easily come into conflict. For instance, as explained earlier, strategies aimed at guaranteeing resource availability weaken the ability to contain costs, and vice versa. 
As the policy entrepreneurs who pressed for the establishment of the NII had foreseen, the contributory system had the potential to generate convergence between their interests and those of MoF officials by partially satisfying the MoF's first-order preferences, thereby assuring its support. The system provided politically convenient revenues and flexibility in fiscal policy. But it did not resolve the core problem of expenditure control, and thus could not eliminate potential conflicts of interest between the MoF and the NII. On the contrary, by fulfilling its function of providing earmarked resources for income maintenance, the social insurance system weakened the ability of the MoF to control expenditure, thereby exacerbating the tension between the ministry's multiple interests. This worried MoF officials from the very beginning, as is evident from their repeated attempts to unify the collection system of the NII with that of the State Revenues Administration, an organization directly under the command of the Treasury (Doron, 2004a). For their part, the objections raised by NII officials and supporters expose their deep fear of becoming financially dependent on the MoF. The NII did not trust the Treasury to provide adequate funding, and worried that any surplus of contributions would be used for other ends. From the viewpoint of the MoF, however, the fear was that growing social entitlements would force it into the position of having to deal with budget shortfalls (Doron and Binder, 1958).

Despite these built-in conflicts over revenue control, until the 1980s a viable institutional equilibrium was achieved. We hypothesize that the MoF's compliance with this equilibrium rested on two essential and complementary preconditions. First, the Israeli state was committed to the developmental state paradigm of political economy, which prioritized the Treasury's extractive capacities over the goal of expenditure control. This commitment resulted from the state's interests in demographic, territorial and military expansion and its ability to achieve rapid economic development through a combination of mass immigration and 'gift capital' from foreign well-wishers (Shalev, 1992). Second, until 1970, social expenditures were relatively low because entitlements were limited, and neither the population nor the insurance system had reached maturity. Social insurance contributions were a convenient means by which the state could appropriate resources.

As we already know, the unique conditions prevailing at the beginning of the 1970s gave the NII and the MoF new reasons to collaborate in expanding the tax base of the social insurance system. The problem was that the cost of new entitlements rapidly outpaced the fiscal benefits resulting from increased charges. By 1972, the MoF was obliged for the first time to transfer funds to the NII (Barkai, 1998). With the two main actors no longer benefiting from convergent returns, the previous equilibrium was weakened. Whereas the NII gained in 
scope and influence, the MoF experienced diminution of its ability to impose budgetary controls.

Macroeconomic changes exacerbated this tension. Following the October 1973 war and subsequent energy price increases, the Israeli economy entered a period of stagnation which, during the early 1980s, was accompanied by recurrent crises in the balance of payments and spiralling inflation. ${ }^{13}$ The developmental state model no longer provided a workable formula for economic growth, nor was it fiscally viable. Runaway inflation exacerbated the problem of expenditure control by veiling the magnitude of the spending carried out by other government agencies and causing the cost of capital subsidies and debt service to balloon. Concurrently, hyper-inflation had devastating consequences for the state's revenue-raising capacities. The resulting fiscal crisis posed a severe threat to fundamental state capacities, but it was not until mid-1985 that a political window of opportunity opened and a team of government and academic economists managed to win approval for the economic stabilization plan (Grinberg, 1991; Barkey, 1994).

Deep cuts in state commitments, reforms of the capital market and additional moves towards embracing the neoliberal paradigm of political economy were part and parcel of the planners' long-term reform strategy. But the immediate concern of the MoF was to stop hyper-inflation in its tracks, thereby allowing the state to regain both its credibility as the factor responsible for economic stability, and its fiscal viability. As we saw earlier, the ministry's first initiatives to reduce employer contributions were driven by its interest in safeguarding stabilization. How important were such macroeconomic policy considerations, relative to strategic fiscal considerations, in causing the MoF to continue down the path of taking over employers' social security obligations? In our judgement, not very important. It is true that the main drift of macroeconomic policy had shifted from Keynesian management of the business cycle, which in the upswing was facilitated by increased payroll taxes, to supply-side policies that mandated cutting such 'taxes on jobs'. But had the MoF been primarily concerned with job creation, it would most likely have opted for targeted wage subsidies, a cheaper and more effective method than blanket reductions in social charges. ${ }^{14}$ The implication is that

\footnotetext{
${ }^{13}$ On the development of the economic crisis and its implications for fiscal and macroeconomic management, see the studies by economists collected by Ben-Porath (1986) and the political economy analysis proposed by Shalev (1992, Chapter 7, 1999).

${ }^{14}$ This was the approach followed by governments in France, Belgium and the Netherlands (Scharpf and Schmidt, 2000, pp. 116, 119). The MoF was certainly aware of the option of targeted wage subsidies, and in fact an NII study of a small-scale targeted programme suggested that it was a more cost-effective means of job creation than subsidizing employers' social charges (Bendelac, 1997). Interestingly, the same study, like a more recent ILO survey of this issue (Marx, 2001), found little evidence for the effectiveness of labour cost subsidies of any kind.
} 
Treasury officials were more concerned with changing the structure of social insurance financing so as to enhance their leverage over the NII, in order to promote the state's ascendant interest in controlling social expenditure.

It is impossible to ascertain at this point whether this was the underlying motive of fiscal bureaucrats from the outset, or if their behaviour became increasingly strategic as they went along. However, debates in the Knesset and its committees surrounding the MoF's initiatives reveal that in the very first hearings, early in 1987, both NII officials and sympathetic members of parliament were concerned that implementation of the Treasury's proposal would lead to growing dependency of the NII upon the MoF. The strongest evidence of fiscal bureaucrats consciously seeking to restructure financing in order to erode the autonomy of social bureaucrats was provided a decade after the first reform of NII finance, when the MoF engineered a byzantine restructuring of health insurance financing. This reform left no doubt that the Treasury was fully aware of the advantages of rendering welfare-state institutions dependent on its contributions to their revenues, in order to tighten its control over their expenditures. ${ }^{15}$

Our argument is, then, that shifting political, ideological and economic circumstances unleashed underlying conflicts of interest, thereby generating susceptibility to institutional change. These changed circumstances altered the relative salience of the dual first-order preferences of the MoF, undermining its continuing consent to the foundational compromise between the interests of the MoF and the NII, which was the bedrock of the institutional equilibrium of the financing system. From the Treasury's perspective, the system was now producing unbalanced returns. By granting the NII a considerable measure of autonomy, and generating the means to expand social programmes, it increasingly undermined the MoF's ability to control expenditures. The ministry's response was to initiate a series of ad hoc measures aimed at bringing about gradual but fundamental institutional change. Using the theoretical lenses proposed earlier, it is easy to see the dialectical character of this development, in which the strengthening and weakening of opposing forces are interchanged, causing movement in a new direction.

\footnotetext{
${ }^{15}$ Briefly, in 1995, employers' contributions to the health insurance system were reduced and two years later were completely annulled. It is clear that this had nothing to do with ameliorating employers' labour costs, since the payroll tax for health was simply re-designated and earmarked for the social insurance system instead. In parallel, the Treasury shifted an equivalent portion of its compensatory funding from the NII to the health system. This complicated move was designed to maximize MoF control over health expenditures when the state first became statutorily responsible for ensuring the funding of citizens' basic health care needs (Bin-Nun, 1999). The resulting dependence of the health insurance system on MoF financing was not purchased at the price of forfeiting the ministry's influence over the NII, since it continued to serve as the Institute's main source of funding.
} 
Nevertheless, just as theories of bricolage and recombination predict, the precise trajectory of change was not without precedent. It will be recalled that the NII was initially constructed on the basis of a unified logic: benefits were financed by a contributory system and distributed according to universal principles. However, this institutional coherence did not last for long. Various elements of non-contributory financing emerged, creating an additional layer on top of the foundation of social insurance (Doron, 1998; Gal, 2004). Though the MoF's role in financing benefits remained relatively minor in comparison with contributions, and while categorical and social assistance programmes together accounted for only a small portion of NII expenditure, the growing hybridity of the system represented a profound transformation of the character of NII functions. It was no longer only a social insurance institution, but also a broader instrument through which the state elected to distribute transfer payments to households. The result was a series of precedents later drawn upon by policy entrepreneurs from the MoF in order to activate change by switching or recombining existing institutional legacies. The idea of bricolage therefore offers a helpful explanation for how institutional change was brought about in the context of the present case study. It does not however answer the critical 'why' question. It is in this respect that we find that a conflict of interest approach can make an indispensable contribution.

\section{Conclusions}

This paper has described a 'quiet revolution' in the financing of social insurance in Israel. Far from being merely a technical innovation, the transfer of employer obligations to the state budget has profoundly altered intra-governmental fiscal and power relations. Consequently, the implications of the reform extend far beyond recalibrating the burden of finance between employers, workers and the state. It has also had significant distributional effects which are beyond the scope of this article. Suffice it to say here that both eligibility criteria and benefit levels have been eroded, due not only to the declining autonomy of the NII but also to the fact that each institutional mode of social insurance financing bases the right to benefits on a different type of legitimation (Koreh, 2004).

This paper opened by distinguishing two unsettled theoretical questions in the study of institutional development: why do institutions become susceptible to change, and what trajectory does change follow? We have argued that a dialectical perspective offers three insights that have much to contribute to understanding these features of institutional change. The first is the significance of opposing forces (conflicts of interest) and their role in preparing the ground for change. The second is the idea that gradual changes may lead to turning points, where 
one force overcomes the other. These two insights together lead to a third: that the trajectory of change can be expected to have a spiral shape.

Path-dependency perspectives need not ignore the role of conflict in institutional genesis or change. Some even draw on political arguments to explain the creation and persistence of institutions (e.g. Thelen, 2003). However, in a path-dependent trajectory, the assumption is that once a certain path is chosen, adaptive institutional adjustments fundamentally reduce the potential for conflict and increase the price of change. That is why forgone options are expected to become less and less viable with time. From a dialectical viewpoint, however, institutional stability must always be seen as contingent on the continuously renewed challenge of managing foundational conflicts of interest. It is true that institutions founded on the basis of a compromise between conflicting firstorder preferences may be consolidated by simultaneously generating and satisfying second-order preferences. Nevertheless, changing circumstances, either endogenous or exogenous to institutions, may cause interests that were previously overpowered and conflicts that were previously resolved to resurface, thereby moving an institution towards a new and quite different equilibrium. It is this dynamism which underlies the potentially continuing relevance of options that appear to have been foregone.

This does not mean that change is not bounded or that actors are unconstrained by institutional limits. The insights of path dependency are invaluable in this respect, but the challenge is to find theoretical room for the notion of 'bounded innovation' (Weir, 1992) while nevertheless anticipating the possibility of institutional reversals. On the basis of the case study presented here, our suggestion is that bounded innovation results from the fact that, as the literature on institutional reconfiguration has emphasized, institutional change is usually slow and gradual. At most moments in time, the inventory of realistic institutional options which actors can utilize in order to pursue their interests is limited. Nevertheless, discarded alternatives that are in the interest of strong actors but come to be seen as no longer feasible may gradually become part of the institutional repertoire available at a later point in time. This means that while innovation is certainly bounded, change is not necessarily unidirectional.

The findings presented here also challenge the claim often made by path dependency theorists that the forces responsible for the genesis of an institution are fundamentally different from those which sustain it over time. While positive feedback may indeed be a condition for the persistence of some institutional arrangements, others may remain intact for long periods of time simply because the conditions which brought them into being continue to prevail. In such cases, where foundational contingencies rather than increasing returns are the glue that holds institutional continuity together, actors whose interests are 
altered as a result of changing conditions may find that the price of change is lower than the costs of continuity.

A dialectical trajectory does not rule out the feedback mechanisms so central to the path-dependency approach, but it invites us to interpret them from a fresh perspective. If institutions are built on arrangements that at least provisionally resolve conflicts of interest, then increasing returns in one dimension of a 'historic compromise' are likely to cause decreasing returns in another. The result can easily be escalation of inbuilt tensions. Contradictions that were initially manageable may, due to unbalanced returns, become intolerable with time. This is how a win-win situation can turn into a zero sum game. Taking this into account means that institutional resiliency is not just a matter of increasing returns, but also of how returns are distributed among different actors, and how they resonate with the different first-order preferences of the same actor. An unbalanced distribution of returns renders institutions susceptible to change by preparing the ground for countervailing action. If, as in the present case study, an institution harbours potentially strong opposing forces, the process of change follows a spiral trajectory. One force stimulates a counter-force and eventually leads to change. This trajectory should be seen as theoretically complementary to the unidirectional one implied by path dependency. Both represent valid evolutionary scenarios.

This analysis does not contradict the possible parallel impact of the exogenous forces to which analysts often appeal in explaining institutional change, such as imported ideational paradigms or moments of profound economic and political crisis. However, we interpret these factors as having the potential to amplify the effects of change-creating contradictions. This understanding dovetails with the theoretical move seen in recent literature, which recognizes that endogenous and exogenous pressures may coincide (Thelen, 2004; Hancke, 2005). The case study presented here demonstrates precisely this pattern of interwoven effects. Furthermore, it illustrates the mechanisms through which these factors gain influence-either by changing the conditions for institutional equilibrium or by escalating contradictions and innate tensions. These mechanisms are certainly not unique to welfare financing. We believe that they are relevant to institutional change in general.

\section{Acknowledgements}

We acknowledge financial support from the Hoffman Fellowship Program (M.K.) and the Israel Science Foundation (M.S.). We are grateful to Kimberly Morgan, Bruno Palier, John Gal, Lev Grinberg, Shlomo Swirski and Miriam Hirschfeld for their helpful suggestions. Dr Daniel Gottlieb and Ms Aviva Geibel of Israel's National Insurance Institute kindly provided us with data. 


\section{References}

Achiram, E. (1969) 'The Alternatives in Economic Policy and National Targets' (in Hebrew), Rivon Lekalkala, 63, 293-298.

Arthur, W. B. (1989) 'Competing Technologies, Increasing Returns, and Lock-in by Historical Events’, Economic Journal, 99, 116-131.

Asiskovitch, S. (2009) 'Digging Their Own Graves: Unexpected Consequences of Institutional Design and Welfare State Changes', Social Policy \& Administration, 43, 226-244.

Avizohar, M. (1978) Money for All: The Development of Social Insurance in Israel (in Hebrew), Tel Aviv, Yariv \& Hadar.

Barkai, H. (1998) The Evolution of Israel's Social Security System: Structure, Time Pattern and Macroeconomic Impact, Aldershot, UK, Ashgate.

Barkey, H. J. (1994) 'When Politics Matter: Economic Stabilization in Argentina and Israel', Studies in Comparative International Development, 29, 41-67.

Beland, D. (2005) Social Security: History and Politics from the New Deal to the Privatization Debate, Lawrence, KS, University Press of Kansas.

Bendelac, J. (1997) 'The Law for Encouraging the Business Sector: Five Years of Paying Incentives to Employers' (in Hebrew). In NII (ed) Annual Survey, Jerusalem, National Insurance Institute.

Ben-Bassat, A. (ed) (2002) The Israeli Economy, 1985-1998: From Government Intervention to Market Economics, Cambridge, MA, MIT Press.

Ben-Bassat, A. and Dahan, M. (2006) The Balance of Power in Budgeting (in Hebrew), Jerusalem, Israel Democracy Institute.

Ben-Porath, Y. (ed) (1986) The Economy of Israel: Maturing through Crisis, Cambridge, MA, Harvard University Press.

Berglas, E. (1969) 'Financing the Defense Budget' (in Hebrew), Rivon Lekalkala, 62, 144-150.

Bernardi, L. and Profeta, P. (2004) Tax Systems and Tax Reforms in Europe, London, Routledge.

Bin-Nun, G. (1999) 'Cost and Sources of the Basket of Services of the National Health Insurance Law' (in Hebrew), Bitachon Soziali, 54, 35-52.

Blyth, M. (2002) Great Transformations: Economic Ideas and Institutional Change in the Twentieth Century, New York, Cambridge University Press.

Brodsky, J., Habib, J., Hirschfeld, M., Siegel, B. and Rockoff, Y. (2003) 'Choosing Overall LTC Strategies: A Conceptual Framework for Policy Development'. In Brodsky, J., Habib, J. and Hirschfeld, M. (eds) Key Policy Issues in Long-term Care, Geneva, World Health Organization, pp. 243-270.

Bruno, M. (1993) Crisis, Stabilization, and Economic Reform: Therapy by Consensus, Oxford, Clarendon Press.

Campbell, J. L. (1993) 'The State and Fiscal Sociology', Annual Review of Sociology, 19, $163-185$. 
Campbell, J. L. (2004) Institutional Change and Globalization, Princeton, NJ, Princeton University Press.

Campbell, A. L. and Morgan, K. J. (2005) 'Financing the Welfare State: Elite Politics and the Decline of the Social Insurance Model in America', Studies in American Political Development, 19, 173-195.

Coser, L. A. (1956) The Functions of Social Conflict, Glencoe, IL, Free Press.

Crouch, C. (2005) Capitalist Diversity and Change: Recombinant Governance and Institutional Entrepreneurs, Oxford and New York, Oxford University Press.

Dahrendorf, R. (1959) Class and Class Conflict in Industrial Society, London, Routledge and Kegan Paul.

David, P. A. (1985) 'Clio and the Economics of QWERTY', American Economic Review, 75, $332-337$.

DeWitt, L. (2007) 'Financing Social Security, 1939-1949: A Reexamination of the Financing Policies of This Period', Social Security Bulletin, 67, 51-69.

Dinstein, Z. (1969) 'Comprehensive Economic Policy' (in Hebrew), Rivon Lekalkala, 63, $251-253$.

Doron, A. (1975) The Struggle over National Insurance in Israel 1948-1953 (in Hebrew), 2nd edn, Jerusalem, The National Insurance Institute.

Doron, A. (1988) 'The Histadrut, Social Policy and Equality', Jerusalem Quarterly, 47, $131-144$.

Doron, A. (1998) 'The Introduction of Supplementary Means Tested Benefits: A Breach in the Universality of the National Insurance Old Age Pension System' (in Hebrew). In Ginosar, P. (ed) Iyunim Betkumat Yisrael [Studies in Zionism, the Yishuv and the State of Israel: A Research Annual] Vol. 8, Sede Boqer, The Ben Gurion Research Center, pp. 398-423.

Doron, A. (1999) 'Welfare Policy in Israel: Developments in the 1980s and 1990s' (in Hebrew). In Nachmias, D. and Menahem, G. (eds) Public Policy in Israel, Jerusalem, The Israel Democracy Institute, pp. 437-474.

Doron, A. (2004a) 'Another Hazard Initiated by the Ministry of Finance' (in Hebrew), Mifneh, 45, accessed at http://www.kibbutz.org.il/mifne/041230_shaar45.htm on August 30, 2009.

Doron, A. (2004b) 'The Changing Status of the National Insurance Institute' (in Hebrew), Bitachon Soziali, 67, 39-61.

Doron, A. and Binder, S. (1958) 'The Unification of Collection of National Insurance Premiums with Income Tax'. In Gross, B. M., Guttman, E. and Dror, Y. (eds) Cases in Public Administration, Jerusalem, The Hebrew University, pp. 48-64.

Doron, A. and Kramer, R. (1991) The Welfare State in Israel-The Evolution of Social Security Policy and Practice, Boulder, CO, Westview.

Ferrera, M. (1996) 'The "Southern Model” of Welfare in Social Europe', Journal of European Social Policy, 6, 17-37. 
Frumkin, H. (1969) 'Curtailment of Consumption and Full Employment of Resources' (in Hebrew), Rivon Lekalkala, 63, 281-285.

Gal, J. (1998) 'Categorical Benefits in Welfare States: Findings from Great Britain and Israel', International Social Security Review, 51, 73-101.

Gal, J. (2004) Social Security in Israel (in Hebrew), Jerusalem, Magnes Press.

Galin, A. and Tabb, J. Y. (1971) 1970—A Turning Point in Israel's Industrial Relations System, Institute for Labour Relations (University of Leuven) Bulletin, 177-188.

Grinberg, L. L. (1991) Split Corporatism in Israel, Albany, NY, State University of New York Press.

Grinberg, L. L. and Shafir, G. (2000) 'Economic Liberalization and the Breakup of the Histadrut's Domain'. In Shafir, G. and Peled, Y. (eds) The New Israel: Peacemaking and Liberalization, Boulder, CO, Westview, pp. 103-127.

Hacker, J. S. (2002) The Divided Welfare State: The Battle over Public and Private Social Benefits in the United States, New York, Cambridge University Press.

Hacker, J. S. (2004) 'Privatizing Risk without Privatizing the Welfare State: The Hidden Politics of Social Policy Retrenchment in the United States', American Political Science Review, 98, 243-260.

Hacker, J. S. and Pierson, P. (2002) 'Business Power and Social Policy: Employers and the Formation of the American Welfare State', Politics and Society, 30, 277-325.

Hancke, B. (2005) 'Institutional Change and Political Economy', European Political Science, 4, 454-463.

Heidenheimer, A. J., Heclo, H. and Adams, C. T. (1975) Comparative Public Policy: The Politics of Social Choice in Europe and America, New York, St Martin's Press.

Hoffnung, M. (2006) Protest and Butter: The Influence of the Black Panther Demonstrations on Social Welfare Budgeting (in Hebrew), Jerusalem, Nevo.

Horowitz, D. (1970) 'Outlines of Economic Policy' (in Hebrew), Rivon Lekalkala, 65-66, $3-8$.

Kato, J. (2003) Regressive Taxation and the Welfare State: Path Dependence and Policy Diffusion, Cambridge, Cambridge University Press.

Kleiman, E. (1998) 'The Waning of Israeli Etatisme', Israel Studies, 2, 146-171.

Knight, J. (1992) Institutions and Social Conflict, Cambridge, UK and New York, NY, Cambridge University Press.

Kop, Y. (ed) (2006) Israel's Social Services 2006, Jerusalem, Taub Center for Social Policy Research in Israel.

Koreh, M. (2003) The Politics of Institutional Change: The Case of Changing the Financing of Health and Welfare Systems in Israel 1986-1997 (in Hebrew), Tel Aviv, Tel Aviv University.

Koreh, M. (2004) 'Changes in the Structure of the Welfare State: From Social Insurance to a Public Service' (in Hebrew), Bitachon Soziali, 67, 62-82. 
Korpi, W. (1974) 'Conflict and the Balance of Power', Acta Sociologica, 17, 99-113.

Korpi, W. (1978) 'Social Democracy in Welfare Capitalism-Structural Erosion, Welfare Backlash and Incorporation?', Acta Sociologica, 21, 97-111.

Korpi, W. (2001) 'Contentious Institutions: An Augmented Rational-Action Analysis of the Origins and Path Dependency of Welfare State Institutions in Western Countries', Rationality and Society, 13, 235-283.

Korpi, W. (2006) 'Power Resources and Employer-centered Approaches in Explanations of Welfare States and Varieties of Capitalism-Protagonists, Consenters, and Antagonists', World Politics, 58, 167-206.

Korpi, W. and Palme, J. (1998) 'The Paradox of Redistribution and Strategies of Equality: Welfare State Institutions, Inequality, and Poverty in the Western Countries', American Sociological Review, 63, 661-687.

Leff, M. H. (1983) 'Taxing the "Forgotten Man": The Politics of Social Security Finance in the New Deal', Journal of American History, 70, 359-379.

Lein, Y. (2000) 'The State, the Business Elite and Coalitions: The Stock Market Tax as a Case in Point'. In Mautner, M. (ed) Distributive Justice in Israel (in Hebrew), Tel Aviv, Ramot, pp. 391-408.

Levi-Faur, D. (1998) 'The Developmental State: Israel, South Korea, and Taiwan Compared', Studies in Comparative International Development, 33, 65-93.

Lindner, J. (2003) 'Institutional Stability and Change: Two Sides of the Same Coin', Journal of European Public Policy, 10, 912-935.

Mahoney, J. (2000) 'Path Dependence in Historical Sociology', Theory and Society, 29, 507-548.

Manow, P. (1997) 'Federalism and the Welfare State: The German Case', Governance, 10, $175-200$.

Martin, C. J. (1991) Shifting the Burden: The Struggle over Growth and Corporate Taxation, Chicago, University of Chicago Press.

Marx, I. (2001) 'Job Subsidies and Cuts in Employers' Social Security Contributions: The Verdict of Empirical Evalution Studies', International Labour Review, 140, 69-83.

Messere, K. (ed) (1998) The Tax System in Industrialized Countries, Oxford, Oxford University Press.

Moe, T. M. (1990) 'Political Institutions: The Neglected Side of the Story', Journal of Law, Economics, and Organization, 6, 213.

Moe, T. M. (2005) 'Power and Political Institutions', Perspectives on Politics, 3, 215-233.

Morag, A. (1967) Public Finance in Israel: Problems and Development (in Hebrew), Jerusalem, Magnes Press.

Myles, J. and Pierson, P. (2001) 'The Comparative Political Economy of Pension Reform'. In Pierson, P. (ed) The New Politics of the Welfare State, Oxford, Oxford University Press, pp. 305-333. 
North, D. C. (1990) Institutions, Institutional Change, and Economic Performance, New York, Cambridge University Press.

OECD (1994) The OECD Jobs Study: Evidence and Explanations, Paris, Organisation for Economic Co-operation and Development.

OECD (1995) The OECD Jobs Study: Taxation, Employment, and Unemployment, Paris, Organisation for Economic Co-operation and Development.

Palier, B. (2002) 'Réduire Les Charges Sociales [Reducing Social Charges]'. In Palier, B. (ed) Gouverner La Sécurité Sociale, Paris, Presses Universitaires de France, Chapter 7.

Palier, B. (2005) 'Ambiguous Agreement, Cumulative Change: French Social Policy in the 1990s'. In Streeck, W. and Thelen, K. A. (eds) Beyond Continuity: Institutional Change in Advanced Political Economies, Oxford, Oxford University Press, pp. 127-144.

Pierson, P. (1994) Dismantling the Welfare State? Reagan, Thatcher, and the Politics of Retrenchment, Cambridge, Cambridge University Press.

Pierson, P. (1998) 'Irresistible Forces, Immovable Objects: Post-Industrial Welfare States Confront Permanent Austerity', Journal of European Public Policy, 5, 539-560.

Pierson, P. (2000) 'Increasing Returns, Path Dependence, and the Study of Politics', American Political Science Review, 94, 251-267.

Pierson, P. (2004) Politics in Time: History, Institutions, and Social Analysis, Princeton, NJ, Princeton University Press.

Pontusson, J. and Swenson, P. (1996) 'Labor Markets, Production Strategies, and Wage Bargaining Institutions-The Swedish Employer Offensive in Comparative Perspective', Comparative Political Studies, 29, 223-250.

Ratson, M. (forthcoming) 'Policy Entrepreneurs, Political Construction and a Window of Opportunity: The Politics of the Second Pension Reform in Israel' (in Hebrew), Soziologia Yisraelit.

Rosenhek, Z. (1998) 'Policy Paradigms and the Dynamics of the Welfare State: The Israeli Welfare State and the Zionist Colonial Project', International Journal of Sociology and Social Policy, 18, 157-202.

Rueda, D. (2005) 'Insider-Outsider Politics in Industrialized Democracies: The Challenge to Social Democratic Parties', American Political Science Review, 99, 61-74.

Scharpf, F. W. and Schmidt, V. A. (eds) (2000) Welfare and Work in the Open Economy (Vol. 1: From Vulnerability to Competitiveness), Oxford and New York, Oxford University Press.

Scharpf, F. W. (2001) 'Employment and the Welfare State. A Continental Dilemma'. In Ebbinghaus, B. and Manow, P. (eds) Comparing Welfare Capitalism: Social Policy and Political Economy in Europe, Japan and the USA, London, Routledge, pp. 270-283.

Shafir, G. and Peled, Y. (2002) Being Israeli: The Dynamics of Multiple Citizenship, Cambridge, UK, Cambridge University Press.

Shafir, G. and Peled, Y. (2005) The New Israel: The Dynamics of a Complex Citizenship (in Hebrew), Tel Aviv, Tel Aviv University Press. 
Shalev, M. (1992) Labour and the Political Economy in Israel, Oxford, Oxford University Press.

Shalev, M. (1999) 'Have Globalization and Liberalization "Normalized" Israel's Political Economy?', Israel Affairs, 5, 121-155.

Shalev, M. (2007) 'The Welfare State Consensus in Israel: Placing Class Politics in Context'. In Mau, S. and Veghte, B. (eds) The Welfare State, Legitimacy and Social Justice, Aldershot, UK, Ashgate, pp. 193-213.

Sjoberg, O. (1999) 'Financing Social Protection in Europe: An Historical Outline'. In Finnish Ministry of Social Affairs and Health (ed) Financing Social Protection in Europe, accessed at http://pre20031103.stm.fi/english/tao/publicat/financing/sjoberg.htm on August 30, 2009.

Sternhell, Z. (1998) The Founding Myths of Israel: Nationalism, Socialism, and the Making of the Jewish State, Princeton, NJ, Princeton University Press.

Streeck, W. and Thelen, K. A. (2005) Beyond Continuity: Institutional Change in Advanced Political Economies, New York, Oxford University Press.

Thelen, K. (1999) 'Historical Institutionalism in Comparative Politics', Annual Review of Political Science, 2, 369-404.

Thelen, K. (2003) 'How Institutions Evolve: Insights from Comparative-Historical Analysis'. In Mahoney, J. and Rueschemeyer, D. (eds) Comparative Historical Analysis in the Social Sciences, New York, Cambridge University Press, pp. 208-239.

Thelen, K. (2004) How Institutions Evolve: The Political Economy of Skills in Germany, Britain, the United States, and Japan, Cambridge and New York, Cambridge University Press.

Titmuss, R. (1958) Essays on the 'Welfare State', London, Allen and Unwin.

Weir, M. (1992) 'Ideas and the Politics of Bounded Innovation'. In Steinmo, S., Thelen, K. and Longstreth, F. (eds) Structuring Politics: Historical Institutionalism in Comparative Analysis, Cambridge, Cambridge University Press, pp. 188-216.

Wilensky, H. L. (2002) Rich Democracies: Political Economy, Public Policy, and Performance, Berkeley, University of California Press.

Yang, J.-J. (2004) 'Democratic Governance and Bureaucratic Politics: A Case of Pension Reform in Korea', Policy and Politics, 32, 193-206.

Zadik, A. (2006) The Reduction of Employer Contributions to National Insurance: Estimation and Social Implications (in Hebrew), Jerusalem, Knesset Research and Information Department. 